and to Dr. W. C. Marshall who performed all the earlier liver biopsies. Dr. J. G. Domenet of Geigy Pharmaceuticals and Dr. D. M. Burley of CIBA generously provided diethylenetriamine penta-acetate and desferrioxamine respectively.

\section{References}

Barry, M. (1973). Fournal of the Royal College of Physicians of London, 8, 52. Barry, M., and Flynn, D. M. (1974). In preparation.

Barry, M., and Sherlock, S. (1971). Lancet, 1, 100.

Berry, C. L., and Marshall, W. C. (1967). Lancet, 1, 1031.
Ellis, J. T., Schulman, I., and Smith, C. H. (1954). American fournal of Pathology, 30, 287.

Frumin, A. M., Waldman, S., and Morris, P. (1952). Pediatrics, 9, 290.

Howell, J., and Wyatt, J. P. (1953). Archives of Pathology, 55, 423.

Marshall, W. A., and Tanner, J. M. (1970). Archives of Disease in Childhood,

45, 13.
Risdon, A. R., Barry, M., and Flynn, D. M. (1974). In preparation.

Smith, R. S. (1962). British Medical fournal, 2, 1577

Smith, R. S. (1964). Annals of the New York Academy of Sciences, 119, 776.

Whipple, G. H., and Bradford, W. L. (1936). Fournal of Pediatrics, 9, 279.

Witzleben, C. L., and Wyatt, J. P. (1961). Fournal of Pathology and Bacteriology, 82, 1 .

Wolman, I. J. (1964). Annals of the New York Academy of Sciences, 119, 736.

Wolman, I. J., and Ortolani, M. (1969). Annals of the New York Academy of Sciences, 165, 407.

\title{
Fine-needle Aspiration Biopsy of Spleen in Diagnosis of Generalized Amyloidosis
}

\section{A. PASTERNACK}

British Medical fournal, 1974, 2, 20-22

\section{Summary}

Fine-needle aspiration biopsy of the spleen was performed on 18 patients shown to have amyloid deposits in other organs and on 17 control patients being investigated for proteinuria. Of the 18 patients with amyloid disease smears of splenic aspirate were positive in all cases, renal biopsy was positive in 16 out of 16 cases, and rectal biopsy was positive in seven out of 11 cases. None of the splenic smears were positive in the 17 control patients and no amyloid was found in the kidney in 15 of these patients on whom renal biopsy was performed. Splenic aspirate biopsy seems to be a simple and safe procedure for the diagnosis of amyloidosis. It is as accurate as renal biopsy and more accurate than rectal biopsy.

Fourth Department of Medicine, University Central Hospital, 00170 Helsinki 17, Finland

A. PASTERNACK, M.D., Associate Professor

\section{Introduction}

Generalized amyloidosis is most often diagnosed by percutaneous biopsy of the kidney or biopsy of the rectal mucasa. There is a need, however, for safer but equally reliable procedures which are easy to perform on large groups of patients. This paper reponts the results of diagnosis by fine-needle aspiration biopsy of the spleen.

\section{Patients and Methods}

Fine-needle aspiration biopsy of the spleen was performed in 35 patients. Eighteen had been or were later shown to have amyloidosis by biopsy of the kidney, rectum, or other organ (table I). The remaining 17 patients ( 7 women, 10 men), who served as controls were in hospital for the investigation of proteinuria (table II). A kidney biopsy was performed within one year in all but five of the patients in the amyloidosis group. The spleen was aspirated by means of a disposable $0.8 \times 80 \mathrm{~mm}$ needle on a disposable $20-\mathrm{ml}$ syringe with Luer adaptor. The spleen was located by percussion and the needle was usually insented into the tenth intercostal space about $3-5 \mathrm{~cm}$ dorsally to the mid-axillary line. To avoid dam-

TABLE I-Clinical Data and Biopsy Findings in 18 Patients with Generalized Amyloidosis. Median Age 42.5 Years

\begin{tabular}{|c|c|c|c|c|c|c|c|c|c|}
\hline \multirow[t]{2}{*}{$\begin{array}{l}\text { Case } \\
\text { No. }\end{array}$} & \multirow[t]{2}{*}{ Sex } & \multirow[t]{2}{*}{$\begin{array}{c}\text { Age } \\
\text { (Years) }\end{array}$} & \multirow[t]{2}{*}{ Diagnosis } & \multicolumn{3}{|c|}{ Amyloid Present in: } & \multicolumn{2}{|c|}{$\begin{array}{l}\text { Amyloid in Aspirate } \\
\text { from Spleen }\end{array}$} & \multirow[t]{2}{*}{ Timing of Biopsies } \\
\hline & & & & Kidney & Rectum & Other Sites & Amount & Localization & \\
\hline 1 & F. & 65 & Rheumatoid arthritis & & + & Gingiva + , liver + , & +++ & Diffuse & \\
\hline 2 & M. & 37 & Ankylosing spondylitis & + & + & $\underset{\text { jejunum }+}{\text { Gingiva }-}$ & & Diffuse & Within a three-year period \\
\hline $\begin{array}{l}3 \\
4 \\
5\end{array}$ & $\begin{array}{l}\text { M. } \\
\text { M. }\end{array}$ & $\begin{array}{l}35 \\
43 \\
50\end{array}$ & $\begin{array}{c}\text { "” } \\
\text { Hereditary amyloidosis } \\
\text { with corneal dystrophy }\end{array}$ & $\stackrel{+}{+}$ & + & $\begin{array}{l}\text { Skin - } \\
\text { Skin }+ \text {, liver }+ \text {, }\end{array}$ & $\begin{array}{l}++ \\
++ \\
+ \\
+\end{array}$ & $\begin{array}{l}\text { Perivascular } \\
\text { Diffuse } \\
\text { Diffuse }\end{array}$ & 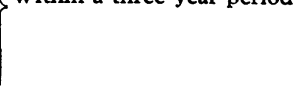 \\
\hline $\begin{array}{r}6 \\
7 \\
8 \\
9 \\
10 \\
11\end{array}$ & $\begin{array}{l}\text { M. } \\
M . \\
M . \\
M . \\
\text { F. }\end{array}$ & $\begin{array}{l}52 \\
34 \\
40 \\
28 \\
57 \\
52\end{array}$ & $\begin{array}{l}\text { Rheumatoid arthritis } \\
\text { "” } \\
\text { Tuberculous osteitis } \\
\text { Hereditary amyloidosis } \\
\text { with corneal dystrophy }\end{array}$ & $\begin{array}{l}+ \\
+ \\
+ \\
+ \\
+ \\
+\end{array}$ & $\overline{-}$ & & $\begin{array}{l}+++ \\
+++ \\
+ \\
+++ \\
+ \\
+\end{array}$ & $\begin{array}{l}\text { Diffuse } \\
\text { Diffuse } \\
\text { Perivascular } \\
\text { Diffuse } \\
\text { Diffuse? } \\
\text { Diffuse }\end{array}$ & Within a one-year period \\
\hline 12 & $\begin{array}{l}\text { M. } \\
\text { F. }\end{array}$ & $\begin{array}{l}46 \\
17\end{array}$ & $\begin{array}{l}\text { Rheumatoid arthritis } \\
\text { Juvenile rheumatoid } \\
\text { arthritis }\end{array}$ & + & $\stackrel{+}{+}$ & & + & $\begin{array}{l}\text { Perivascular ? } \\
\text { Diffuse }\end{array}$ & \\
\hline $\begin{array}{l}14 \\
15 \\
16 \\
17\end{array}$ & $\begin{array}{l}\text { M. } \\
\text { F. } \\
\text { F. }\end{array}$ & $\begin{array}{l}36 \\
66 \\
54 \\
42\end{array}$ & $\begin{array}{l}\text { Ankylosing spondylitis } \\
\text { Bronchiectasiae } \\
\text { Skin tuberculosis }\end{array}$ & $\begin{array}{l}+ \\
+ \\
+ \\
-\end{array}$ & + & Jejunum - & $\begin{array}{l}++ \\
+++ \\
++ \\
+++\end{array}$ & $\begin{array}{l}\text { Diffuse } \\
\text { Diffuse } \\
\text { Diffuse } \\
\text { Diffuse }\end{array}$ & $\begin{array}{l}\text { During the same period in } \\
\text { hospital }\end{array}$ \\
\hline 18 & F. & 38 & Unknown & + & - & & +++ & Perivascular & \\
\hline
\end{tabular}


TABLE II-Diagnosis in Control Group of Patients (7 Women and 10 Men) Presenting with Proteinuria

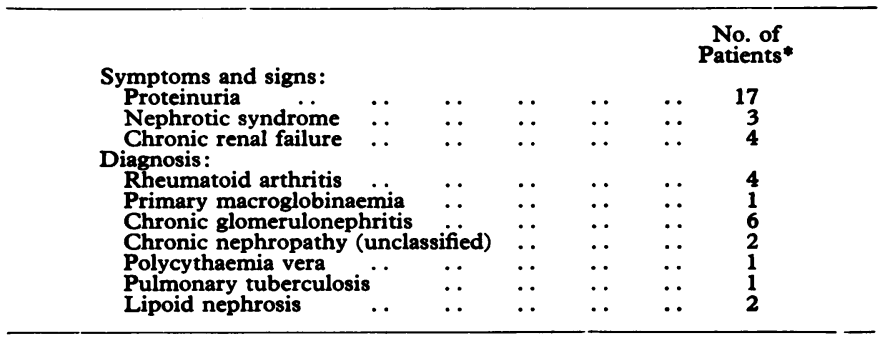

*Median age 44 years; range 18-86 years.

age to the spleen, the patients were asked to catch their breath in mid-expiration. Local anaesthesia was unnecessary.

The tissue smears were stained with Congo red (Puchtler et al., 1962) and positive standand slides were included in each batch as a control of the staining technique. Red staining changing to deep green in polarized light was considered a pasitive sign of amyloidosis. All the smears were pooled, coded, and looked at randomly by me and by a technician with only limited previous experience in histochemical techniques. We achieved complete agreement in interpretation.

\section{Results}

All splenic aspirates obtained from the 18 patients in the amyloidosis group contained a substance that stained with Congo red and gave the green colour specific to amyloid in polarized light (figs. 1 and 2). This deep green birefringence is impressive and is easily distinguishable from all other colour changes in polarized light. In smears from some of the patients several tissue fragments consisted of positivelystaining noncellular substance surnounded by mononuclear cells. In others only isolated pieces of noncellular material were noted, and in such instances the amyloid was clearly localized to structures representing the vessel wall.
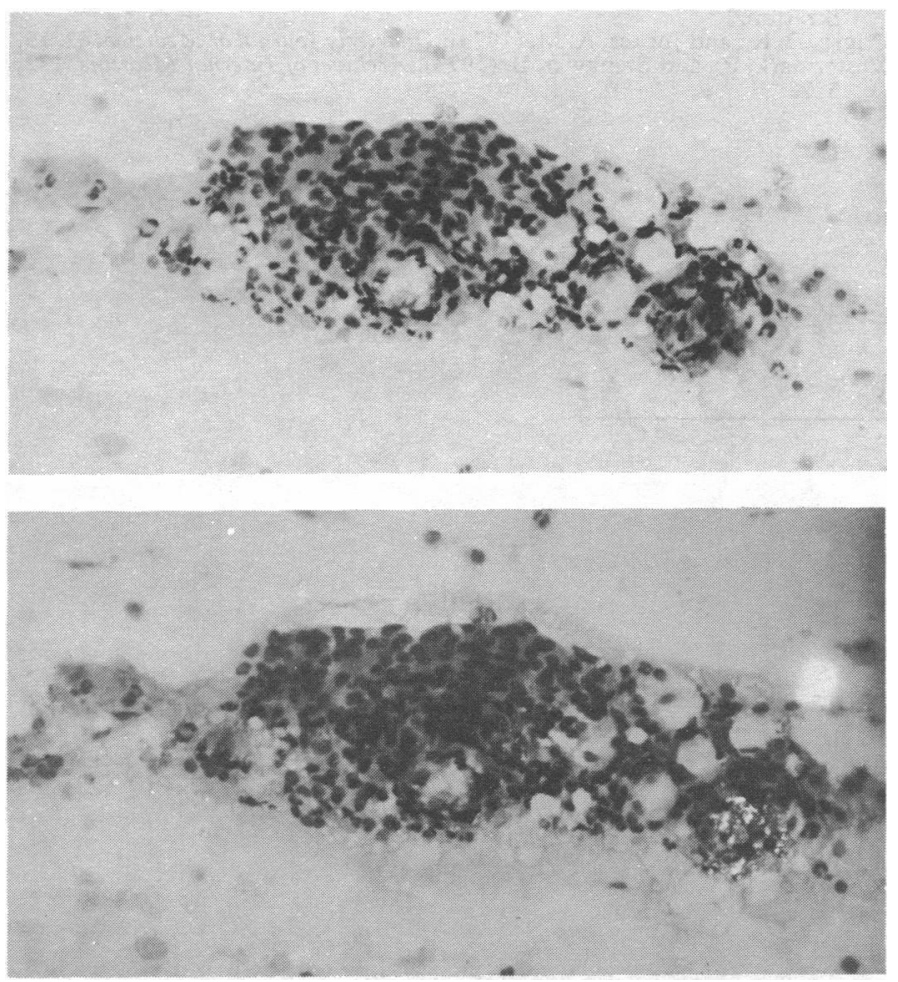

FIG. 1-Above: Fine-needle aspiration biopsy smear showing amyloid of spleen. (Congo red. $\times 160$.) Below: Same area in polarized light. Green birefringence of amyloid shown in perivascular distribution.
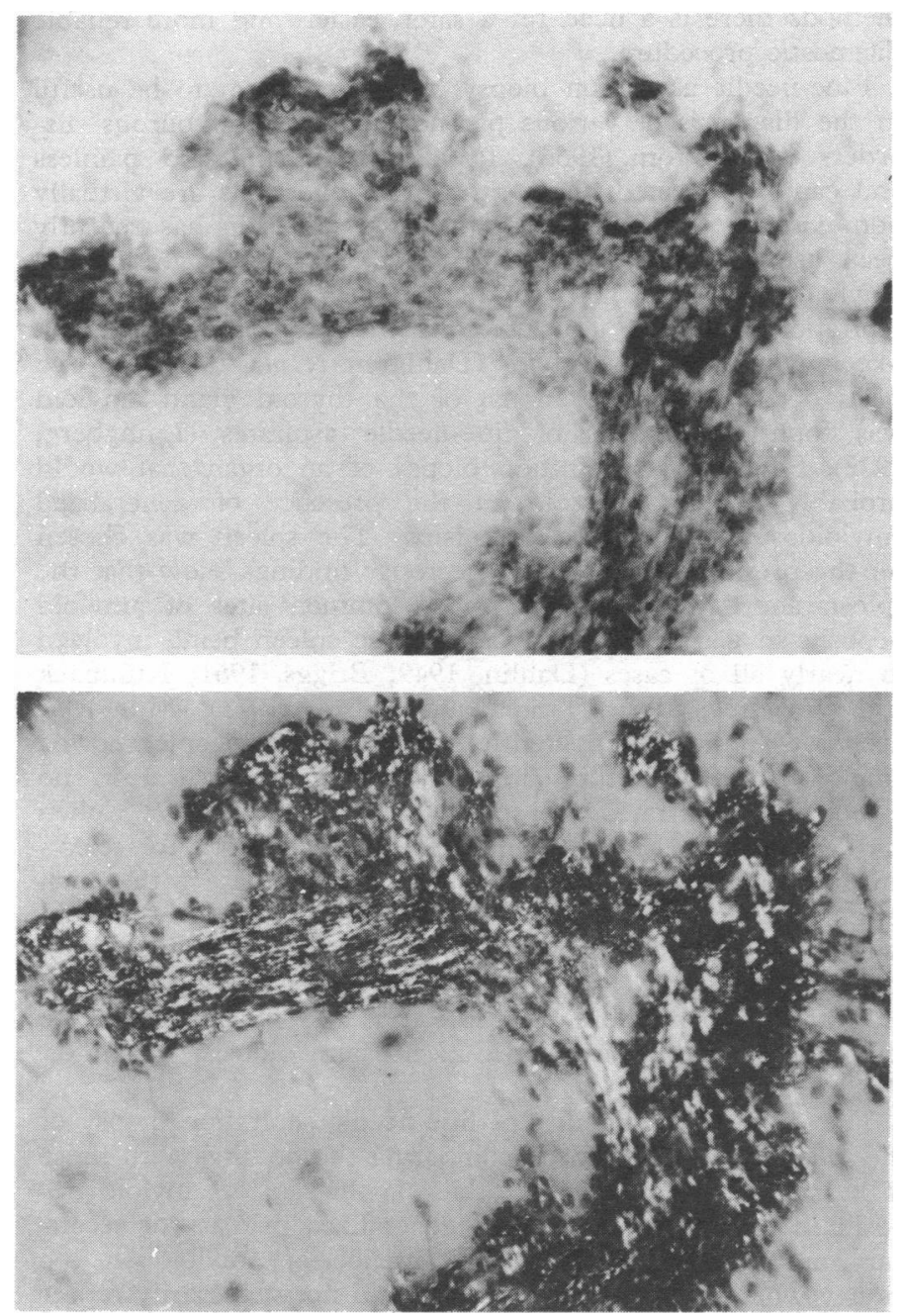

FIG. 2-Above: Fine-needle aspiration biopsy smear showing amyloid of FIG. 2-Above: Fine-needle aspiration biopsy smear showing amyloid of spleen. (Congo red. $\times 180$.) Below: Sam

In the smears from the 17 patients in the control group areas were noted in which a noncellular substance turned faintly red when stained with the Congo dye but did not show the green birefringence in polarized light. They were therefore regarded as negative. Four patients in the amyloidosis group have since died (cases 1, 7, 9, and 15) and necropsy has confirmed the presence of amyloidosis. No complications were seen during the study.

\section{Discussion}

Biopsy of parenchymal organs and of the rectum is the most dependable of the established methods of diagnosing generalized amyloidosis. Renal biopsy is the most reliable and gives positive results in $87-100 \%$ of cases (Blum and Sohar, 1962; Kuhlbäck and Wegelius, 1966; Triger and Joekes, 1973). Biopsy of the rectal wall has a reponted accuracy of $75-97 \%$ (Gafni and Sohar, 1960; Blum and Sohar, 1962), and because it is easily carried out it has been suggested (Missmahl, 1968) as a way of following the progress of the disease. Pettensson and Wegelius (1972) reported jejunal biopsy to be highly reliable. Biopsy of tissue from other sites-for example, liver and gingiva - have given less satisfactory results (Blum and Sohar, 1962). Neventheless, because of the risk and the inconvenience of percutaneous renal biopsy and of jejunal suction biopsy and the relative inaccuracy of other biopsy 
methods there is a need for a safer, easier, and more reliable diagnostic procedure.

Fine-needle aspiration biopsy thas been shown to be useful in the diagnosis of various parenchymal and tumourous disorders (Söderström, 1966). It is nontraumatic and painless and can be repeated many times. Complications are vintually non-existent. Fine-needle aspiration of the skin has recently been used in eight patients for the diagnosis of generalized amyloidosis (Westermark and Stenkvist, 1973). Fine-needle aspiration has been also used for the diagnosis of tumourlike amyloidosis of the lung (Dahlgren et al., 1970). In two cases of medullary caroinoma of the thyroid gland amyloid was found in smears of fine-needle aspirates (Ljungberg, 1972). Fine-needle aspiration biopsy of an organ that would probably contain amyloid in the presence of generalized amyloidosis thus seemed promising. The spleen was chosen for the present study because necropsy findings show that the spleen and kidneys are the most common sites of amyloid deposits in generalized amyloidosis, the spleen being involved in nearly all of cases (Dahlin, 1949; Briggs, 1961; Kuhlbäck and Wegelius, 1966; Triger and Joekes, 1973). Moreover, necropsy studies of apparently normal elderly people showed amyloid to have accumulated in several organs but in no case had it infiltrated the spleen (Ravid et al., 1967; Cohen and Wills, 1968; Limas et al., 1973). Other reasons for selecting the spleen for the present study were the ease with which it can be approached; the diffuse distribution of amyloid within it, at least in secondary amyloidosis (Dahlin, 1949); and its consistency, which makes it especially suitable for aspiration. Funthermore, the spleen is the first organ to be affected in experimentally-induced amyloidosis (Letterer, 1968).

The diagnostic reliability of fine-needle aspiration biopsy of the spleen may be tested by comparing the findings with those of kidney biopsy, since the kidney is the site of amyloid deposits in practically all cases of generalized primary or secondary amyloidosis. Neventheless, absence of amyloid in the kidney when found in the spleen would not necessarily represent a false-positive finding in the spleen, since splenic amyloidosis may be indicative of a preamyloidotic state. The results of splenic biopsy may also be compared with those of rectal biopsy. Since the intervals between biopsy of the different organs in the present study were brief the findings reflected the actual state of amyloidosis and provided valid comparisons.
The findings of splenic aspiration biopsy were positive in all the patients known to have amyloid deposits in the kidney and were negative in the 15 patients in which the kidney findings were also negative. Moreover, the findings on splenic biopsy were positive in all patients in whom the rectal biopsy findings were positive, but in 11 patients with positive splenic findings the rectal biopsy was also positive in only seven. These results suggest that fine-needle aspiration biopsy of the spleen is as reliable as kidney biopsy in the diagnosis of amyloidosis and more reliable than rectal biopsy.

Fine-needle aspiration of the spleen has the additional advantage of being a bedside procedure, easy to perform and painless. The entire procedure, from aspiration to reading the result, can be completed in less than one hour. The Congo red staining and examination under polarized light make positive smears easily recognizable. Finally, the procedure is safe provided it is not practised on patients with a bleeding tendency. Infection is not a contraindication (Söderström, 1966). A total of 947 fine-needle aspiration splenic biopsies were performed by Berg et al. (1973) without a single complication.

\section{References}

Berg, B., Ståhl, E., and Söderström, N. (1973). Scandinavian fournal of Haematology, 10, 59

Blum, A., and Sohar, E. (1962). Lancet, 1, 721.

Briggs, G. W. (1961). Annals of Internal Medicine, 55, 943.

Cohen, A. S., and Wills, A. A. (1968). In Amyloidosis, ed. E. Mandema, L. Ruinen, J. H. Scholten, and A. S. Cohen, p. 438. Amsterdam, Excerpta Medica.

Dahlgren, S. E., Lewenhaupt, A., and Ovenfors, C.-O. (1970). Acta Pathologica et Microbiologica, Scandinavica, Section A, 78, 1.

Dahlin, D. C. (1949). Annals of Internal Medicine, 31, 105

Gafni, J., and Sohar, E. (1960). American fournal of Medical Sciences, 240, 332.

Kuhlbäck, B., and Wegelius, O. (1966). Acta Medica Scandinavica, 180, 737. Letterer, E. (1968). In Amyloidosis, ed. E. Mandema, L. Ruinen, J. H. Scholten, and A. S. Cohen, p. 363. Amsterdam, Excerpta Medica.

Limas, C., Wright, J. R., Matsuzaki, M., and Calkins, E. (1973). American fournal of Medicine, 54, 166.

Fournal of Medicine, S4, 166.
Ljungberg, O. (1972). Acta Cytologica, (Balt.), 16, 253.

Ljungberg, O. (1972). Acta Cytologica, (Balt.), 16, 253 . Scholten, and A. S. Cohen, p. 429. Amsterdam, Excerpta Medica.

Pettersson, T., and Wegelius, O. (1972). Gastorenterology, 62, 22.

Puchtler, H., Sweat, F., and Levine, M. (1962). Fournal of Histochemistry and Cytochemistry, 10, 355.

Ravid, M., Gafni, J., Sohar, E., and Missmahl, H. P. (1967). fournal of Clinical Pathology, 20, 15

Söderström, N. (1966). Fine-Needle Aspiration Biopsy. New York, Grune and Stratton. Triger, D. R., and Joekes, A. M. (1973). Quarterly fournal of Medicine, 42, 15.
Westermark, P., and Stenkvist, B. (1973). Archives of Internal Medicine, 132, 522 